\title{
POTASSIUM FERTILIZATION FOR OPTIMIZATION OF ONION PRODUCTION $^{1}$
}

\author{
SAULO DE TÁRCIO MARROCOS ${ }^{2}$, LEILSON COSTA GRANGEIRO ${ }^{3 *}$, VALDÍVIA DE FÁTIMA LIMA DE \\ SOUSA $^{3}$, RAYANNE MARIA PAULA RIBEIRO $^{3}$, CARLOS JARDEL CORDEIRO $^{3}$
}

\begin{abstract}
Information about the response of onion to different potassium doses may contribute to optimizing the use of fertilizers and, consequently, make the activity more profitable and environmentally sustainable. In this context, the aim of this study was to evaluate the effects of doses of potassium on onion yields. Two field experiments were carried out in the periods of September to December 2012 and April to July 2013. The experimental design used was completely randomized blocks with four replications. The treatments corresponded to the potassium doses $\left(0,36,72,108,144\right.$ and $180 \mathrm{~kg} \mathrm{ha}^{-1}$ of $\left.\mathrm{K}_{2} \mathrm{O}\right)$. Potassium fertilization promoted an increase in the content of $\mathrm{K}$ in the leaf, commercial and total yield, with the maximum obtained in the dose of $180 \mathrm{~kg} \mathrm{ha}^{-1}$ of $\mathrm{K}_{2} \mathrm{O}$. The maximum overall and commercial yields were respectively 54.69 and $54.12 \mathrm{t} \mathrm{ha}^{-1}$ in the experiment of September to December 2012 and 47.39 and $46.39 \mathrm{t} \mathrm{ha}^{-1}$ in that of April to July 2013.
\end{abstract}

Keywords: Allium cepa L.. Planting period. Productivity.

\section{FERTILIZAÇÃo POTÁSSICA PARA OTIMIZAÇÃO DA PRODUÇÃO DE CEBOLA}

RESUMO - Informações sobre a reposta da cebola a diferentes doses de potássio podem contribuir para a otimização do uso de fertilizantes e, consequentemente, tornar a atividade mais rentável e ambientalmente sustentável. Nesse contexto, o objetivo do trabalho foi avaliar os efeitos de doses de potássio na produtividade da cebola. Para isso dois experimentos de campo foram realizados nos períodos de setembro a dezembro de 2012 e abril a julho de $2013 \mathrm{O}$ delineamento experimental foi em blocos casualizados completos com quatro repetições. Os tratamentos corresponderam às doses de potássio $\left(0,36,72,108,144\right.$ e $\left.180 \mathrm{~kg} \mathrm{ha}^{-1} \mathrm{de} \mathrm{K}_{2} \mathrm{O}\right)$. A adubação potássica promoveu aumento do teor de $\mathrm{K}$ na folha, produtividade comercial total, com o máximo obtido na dose de $180 \mathrm{~kg} \mathrm{ha}^{-1}$ de $\mathrm{K}_{2} \mathrm{O}$. As produtividades máximas totais e comerciais foram respectivamente de 54,69 e 54,12 t ha ${ }^{-1}$ no experimento de setembro a dezembro de 2012 e 47,39 e 46,39 tha $^{-1}$ de abril a julho de 2013.

Palavras-chaves: Allium cepa L.. Período de plantio. Produtividade.

\footnotetext{
*Corresponding author

${ }^{1}$ Received for publication in $12 / 19 / 2016$; accepted in $07 / 26 / 2017$

Paper extracted from the doctoral thesis of the first author.

${ }^{2}$ Department of Agricultural, Instituto Federal de Educação, Ciência e Tecnologia do Amapá, Macapá, AM, Brazil; saulotpm@yahoo.com.br.

${ }^{3}$ Agricultural Sciences Center, Universidade Federal Rural do Semi-Árido, Mossoró, RN, Brazil; leilson@ufersa.edu.br, valdivia_sousa@hotmail.com, rayanne_tab@hotmail.com, carlos-jardel@hotmail.com.
} 


\section{INTRODUCTION}

The onion (Allium cepa L.) is one of the most consumed vegetables worldwide and the third most cultivated species in Brazil, having a planted area of 59,830 hectares and production of about 1.65 million tons in 2014 (IBGE, 2016). The average yield was $27.8 \mathrm{t} \mathrm{ha}^{-1}$, which is considered low if compared to other onion-producing countries. Despite its importance, researches relating to nutrition and fertilization of this culture are incipient, which in part makes it difficult to increase productivity in the producing regions.

Potassium $(\mathrm{K})$ plays an important role in plant metabolic processes, such as the synthesis, transport and storage of photoassimilates (HAWKESFORD et al., 2012). Potassium is considered the most essential nutrient to onions. In studies on nutrient accumulation in onions, Vidigal, Moreira and Pereira (2010) obtained maximum accumulations of $\mathrm{K}$ $228 \mathrm{mg} \mathrm{plant}^{-1}$ (transplanting of seedlings) and $242 \mathrm{mg}$ plant $^{-1}$ (no-till). Aguiar Neto et al. (2014) observed accumulations of $\mathrm{K}$ varying from 218.21 to $790.50 \mathrm{mg}$ of plant ${ }^{-1}$, according to the cultivar and the planting site.

Responses of onion crops to potassium fertilization are not always significant, or are divergent, despite the large amount of this nutrient extracted. Doses vary considerably as a function of cultivars and soil and weather conditions in the cultivated region. In Brazil, Resende, Costa and Pinto (2009) found diverse behaviors of the Alfa Tropical cultivar, according to the dose of $\mathrm{K}$ applied. Without $\mathrm{N}$ addition, combined with $180 \mathrm{~kg} \mathrm{ha}^{-1}$ of $\mathrm{K}_{2} \mathrm{O}$, yields of $42.1 \mathrm{tha}^{-1}$ of commercial onion bulbs were possible. However, with the application of $97 \mathrm{~kg} \mathrm{ha}^{-1}$ of $\mathrm{N}$, without $\mathrm{K}$ supply, estimated yields were of the order of $36.5 \mathrm{t} \mathrm{ha}^{-1}$ of onion bulbs. However, an application of $90 \mathrm{~kg} \mathrm{ha}^{-1}$ of $\mathrm{K}_{2} \mathrm{O}$ and $180 \mathrm{~kg} \mathrm{ha}^{-1}$ of $\mathrm{N}$ yielded $36.2 \mathrm{t} \mathrm{ha}^{-1}$ of bulbs, which indicates that the responses to potassium supply may vary considerably, with or without nitrogen addition. Cecílio Filho et al. (2010) obtained higher yields of Superex onion $\left(89.5 \mathrm{t} \mathrm{ha}^{-1}\right)$ with $150 \mathrm{~kg} \mathrm{ha}^{-1}$ of $\mathrm{N}$ and $150 \mathrm{~kg} \mathrm{ha}^{-1}$ of $\mathrm{K}_{2} \mathrm{O}$.

The main onion-producing regions of Brazil have official recommendations adapted to their soil conditions, which show variations among the producing states. In the state of Rio Grande do Norte there is no official fertilization recommendation bulletin, and the amount of fertilizer applied is based on information from private companies, recommendations from other regions and on the experience acquired by producers. The average amount of potassium used varies from 200 to $300 \mathrm{kgha}^{-1}$ of $\mathrm{K}_{2} \mathrm{O}$. The form and the management are different from other regions, because the drip irrigation system is employed and it uses fertirrigation.

Information on the response of onion to different potassium doses may contribute to optimal use of fertilizers and, consequently, make onion crops more profitable and environmentally sustainable. In this context, the aim of this study was to assess the effects of different doses of potassium on onion yields.

\section{MATERIAL AND METHODS}

Two experiments were carried out in Mossoró-RN, from September to December 2012 (Experiment 1 - E1) and from April to July 2013 (Experiment 2 - E2). The soil in the experimental area was classified as Red Yellow Argisol. The chemical analyses of the soil conducted with samples taken at depths of between 0 and $20 \mathrm{~cm}$ before the experiments began produced the following results from $\mathrm{E} 1$ and $\mathrm{E} 2$, respectively: 7.0 and $7.7 \mathrm{pH}\left(\mathrm{H}_{2} \mathrm{O}\right) ; 3.5$ and $3.8 \mathrm{~g} \mathrm{~kg}^{-1}$ organic matter; 9.90 and $10.60 \mathrm{mg} \mathrm{dm}^{-3} \mathrm{P}$ (Mehlich); 0.25 and $0.28 \mathrm{cmol}_{\mathrm{c}} \mathrm{dm}^{-3} \mathrm{~K} ; 1.50$ and $1.60 \mathrm{cmol}_{\mathrm{c}} \mathrm{dm}^{-3} \mathrm{Ca}$; 0.10 and $0.12 \mathrm{cmol}_{\mathrm{c}} \mathrm{dm}^{-3} \mathrm{Mg}$. During E1 and E2, rainfall was 44 and $450 \mathrm{~mm}$, average temperatures were 26.9 and $25.4{ }^{\circ} \mathrm{C}$, and the average relative humidity was 46.0 and $64.6 \%$, respectively.

The treatments corresponded to the potassium doses $\left(0,36,72,108,144\right.$ and $180 \mathrm{~kg} \mathrm{ha}^{-1}$ of $\left.\mathrm{K}_{2} \mathrm{O}\right)$. The experimental design used was completely randomized blocks with four replications. The experimental area consisted of $3.0 \times 1.0 \mathrm{~m}$ planting beds with eight plant rows with a spacing of $0.10 \times 0.10 \mathrm{~m}$, comprising a total area of $3.0 \mathrm{~m}^{2}$. The useful area was $1.68 \mathrm{~m}^{2}$, corresponding to the six central rows, excluding one plant from each end of the bed.

Soil preparation consisted of ploughing and harrowing followed by the construction of the planting beds. Planting fertilization was done according to the soil analysis and as recommended by Cavalcanti (2008), using half of the recommended phosphorous dose $\left(67.5 \mathrm{~kg} \mathrm{ha}^{-1}\right)$ as triple superphosphate.

Drip irrigation with three hoses per bed at a spacing of $0.30 \mathrm{~m}$ was used, with self-compensating drippers and a flow rate of $1.40 \mathrm{~L} \mathrm{~h}^{-1}$, with a distance of $0.20 \mathrm{~m}$ between them. Irrigation was performed on a daily basis, according to the culture requirements.

Transplanting was carried out 53 and 57 days after sowing in E1 and E2, respectively, when the seedlings were $15-20 \mathrm{~cm}$ tall. The cultivar used was Vale Ouro IPA 11.

The fertirrigation was initiated 10 days after transplanting (DAT) and maintained until 70 DAT, and its distribution throughout the cycle was established based on the rate of nutrient absorption by the onion culture, according to Aguiar Neto et al. (2014). Potassium doses, according to each treatment, were administered using potassium 
chloride as source. In total, $135.0 \mathrm{~kg} \mathrm{ha}^{-1}$ of $\mathrm{N}$, $45.0 \mathrm{~kg} \mathrm{ha}^{-1}$ of $\mathrm{S}$ and $67.5 \mathrm{~kg} \mathrm{ha}^{-1}$ of $\mathrm{P}_{2} \mathrm{O}_{5}$, in the form of urea, ammonium sulfate and monoammonium phosphate (MAP), were used.

The foliar nitrogen, phosphorus and potassium contents were determined 45 days after transplanting, using the highest leaf of the plant in accordance with the instructions of Trani and Raij (1997).

When nearly $70 \%$ of the plants had toppled over, irrigation was interrupted so that the natural ripening of the plant could occur in the field. The plants were then pulled out and the parts above the ground and roots were discarded. The characteristics assessed were the following:

The bulbs were classified the largest transverse diameter, based on the classification of CEAGESP (2001), into Class 1 (noncommercial) bulbs, with a diameter of $<35$; Class 2 bulbs, with a diameter of 35-50 mm; Class 3 bulbs, with a diameter of $50-75 \mathrm{~mm}$; Class 4 bulbs, with a diameter of 75-90 mm;and Class 5 bulbs, with a diameter of $>90 \mathrm{~mm}$.

Commercial bulbs yield, total weight of bulbs with a diameter of $>35 \mathrm{~mm}$.

Noncommercial yield, total weight of bulbs with a diameter of $<35 \mathrm{~mm}$ (Class 1 ).

Overall bulbs yield, total weight of bulbs harvested in the useful area of the parcel.

Mean bulb weight obtained by dividing the commercial bulbs weight by the number of commercial bulbs in the useful area of the parcel.

Analysis of variance of the data of the characteristics evaluated was performed separately for each experiment using the F test. Joint analysis of the experiments using SAS software followed. Fitting procedure of response curve on each characteristic was carried out in function of the potassium doses using software Table Curve Package (SCIENTIFIC, 1991).

\section{RESULTS AND DISCUSSION}

\section{Foliar NPK contents}

A significant interaction between potassium (K) doses and planting time (PT) occurred only for foliar potassium content, while phosphorous and nitrogen contents were not influenced by other factors.

The foliar $\mathrm{N}$ and $\mathrm{P}$ mean contents found in both cultivation periods were 28.3 and $7.7 \mathrm{~g} \mathrm{~kg}^{-1}$, respectively. Comparing these contents with the ranges considered appropriate for onions, according to Trani and Raij (1997), it can be seen that the N content was within the suitable range $\left(25-40 \mathrm{~g} \mathrm{~kg}^{-1}\right)$ and the $\mathrm{P}$ content was above $\left(2-5 \mathrm{~g} \mathrm{~kg}^{-1}\right)$. In other vegetables, such as lettuce and pumpkin, no effects of $\mathrm{N}$ and $\mathrm{P}$ contents were found following the addition of potassium to the soil (KANO; CARDOSO; BÔAS, 2012; ARAÚJO et al., 2012).

Foliar potassium content increased linearly with doses of $\mathrm{K}$, in both cultivation periods. In E1, the leaf potassium content rose from $41.4 \mathrm{~g} \mathrm{~kg}^{-1}$ (without the application of $\mathrm{K}$ ) to $64.7 \mathrm{~g} \mathrm{~kg}^{-1}$ with the $180 \mathrm{~kg} \mathrm{ha}^{-1} \mathrm{~K}_{2} \mathrm{O}$, while in E2 it rose from $43.6 \mathrm{~g} \mathrm{~kg}^{-1}$ to $47.2 \mathrm{~g} \mathrm{~kg}^{-1}$ (Figure 1). This increase was probably due to the increased $\mathrm{K}$ level in the soil, as a result of the application doses of this nutrient, which caused more K uptake by the plant.

In the two planting times (E1 and E2), the conditions of the experiments (genetic material, location, default initial soil, fertilizers) were similar, yet different foliar $\mathrm{K}$ level values were obtained. The increases observed in $\mathrm{K}$ levels were $56 \%$ and $8 \%$, respectively, in E1 and E2, considering the treatment without application of $\mathrm{K}$ and the maximum dose $\left(180 \mathrm{~kg} \mathrm{ha}^{-1} \mathrm{~K}_{2} \mathrm{O}\right)$. The higher rainfall in E2 $(450 \mathrm{~mm})$ favored higher leaching of $\mathrm{K}$ in the soil, and consequently lower absorption by plants.

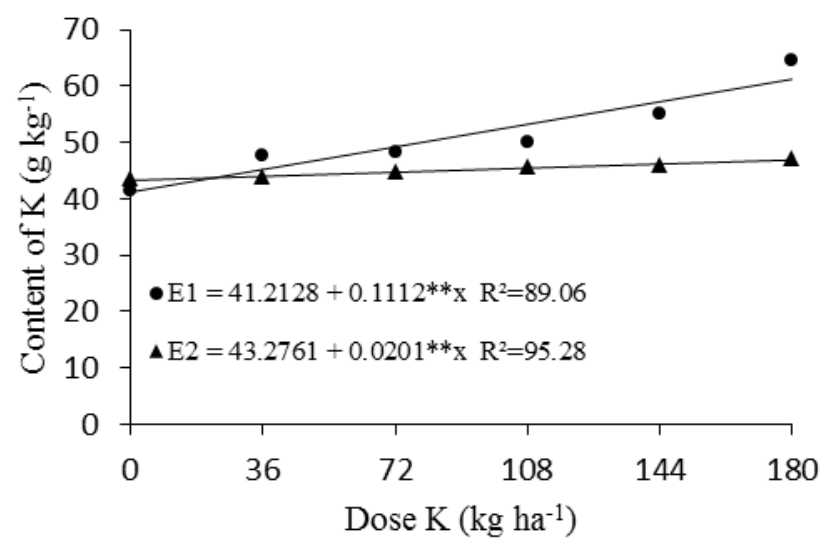

Figure 1. Potassium foliar content as a function of K doses and planting time (E1 - September to December 2012, and E2 April to July 2013). 
The potassium contents found in the leaves were in line with those described by Trani and Raij (1997) as adequate for onion. Even in the treatment without the addition of potassium, leaf contents were within the adequate range, and no potassium deficiency was observed in the plants in this experiment.

\section{Mean bulb weight and yield}

Mean bulb weight (MBW) was significantly influenced by the potassium doses and planting time, considered separately. There was a linear increase of MBW as a function of $\mathrm{K}$ doses, with a maximum of $106.7 \mathrm{~g}$ obtained with $180 \mathrm{~kg} \mathrm{ha}^{-1} \mathrm{~K}_{2} \mathrm{O}$. With regard to the experiment without $\mathrm{K}$ addition, the increase was $22.81 \%$ (Figure 2). These results corroborate those obtained by Verma and Sing (2012) in a study where they evaluated $\mathrm{K}$ doses between 0 and $90 \mathrm{~kg} \mathrm{ha}^{-1}$ of $\mathrm{K}_{2} \mathrm{O}$ and increased mean bulb weight, obtaining a maximum of $61 \mathrm{~g}$ for a dose of $90 \mathrm{~kg} \mathrm{ha}^{-1}$.

Application of potassium to onion crops raises its concentration in the tissues and reduces water potential, resulting in more water storage in the tissues and, consequently, an increase in mass of the draining organs, such as the bulb (BUGARÍNMONTOYA et al., 2002). In this regard, the addition of potassium probably increased the translocation of photoassimilates to the bulb, thereby increasing its average weight.

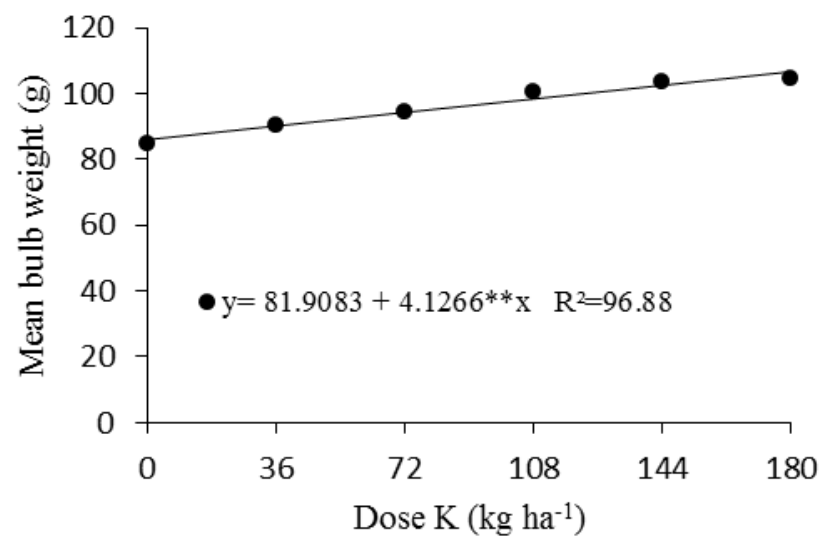

Figure 2. Mean bulb weight as a function of $\mathrm{K}$ doses.

The mean bulb weight was approximately $4 \%$ higher in E1 than in E2 (Table 1). For the bulb percentage of Class $2(\mathrm{C} 2)$ and $3(\mathrm{C} 3)$ onions, only the planting time had an influence, and Class 4 onions were not influenced by any factor. The bulb percentage of Class 2 onions was higher in E2, while that of Class 3 was higher in E1. The Class 4 bulb percentage was not influenced by dosage and planting times. The lower rainfall that occurred in E1 reduced $\mathrm{K}$ runoff in the soil, and consequently increased the availability and absorption of the same by onion plants, and the production of photoassimilates.

Table 1. Mean bulb weight (MBW), onion bulb percentage of Classes 2 (C2), 3 (C3) and 4 (C4), cv. IPA 11, according to the planting time.

\begin{tabular}{lcccc}
\hline \multicolumn{1}{c}{ Planting time } & MBW & C2 & C3 & C4 \\
\cline { 3 - 5 } & $(\mathrm{g})$ & & $(\%)$ & \\
\hline September to December 2012 & $98.43 \mathrm{a}$ & $15.20 \mathrm{~b}$ & $80.57 \mathrm{a}$ & $2.94 \mathrm{a}$ \\
April to July 2013 & $94.27 \mathrm{~b}$ & $27.02 \mathrm{a}$ & $68.32 \mathrm{~b}$ & $3.24 \mathrm{a}$ \\
\hline
\end{tabular}

Means followed by the same letters in the column are not different $\mathrm{F}$ test.

The difference between Class 2 and Class 3 bulb percentage in the planting times was probably due to the higher rainfall rate observed in E2, which caused more nutrient runoffs and a greater production of smaller bulbs. In addition, rains also caused the occurrence of purple blotch (Alternaria porri). The action of this disease probably contributed to the lower percentage of Class 3 bulbs found in E2 than in E1.
The maximum estimated OY was 54.69 and $47.39 \mathrm{tha}^{-1}$ for E1 and E2, respectively. In E1, it was $15.40 \%$ higher than in E2. Similar behavior was observed for CY, where the E1 yield was $16.66 \%$ higher than that of E2, with maximum estimates of 54.12 and $46.39 \mathrm{t} \mathrm{ha}^{-1}$ for $\mathrm{E} 1$ and $\mathrm{E} 2$, respectively (Figure 3). 

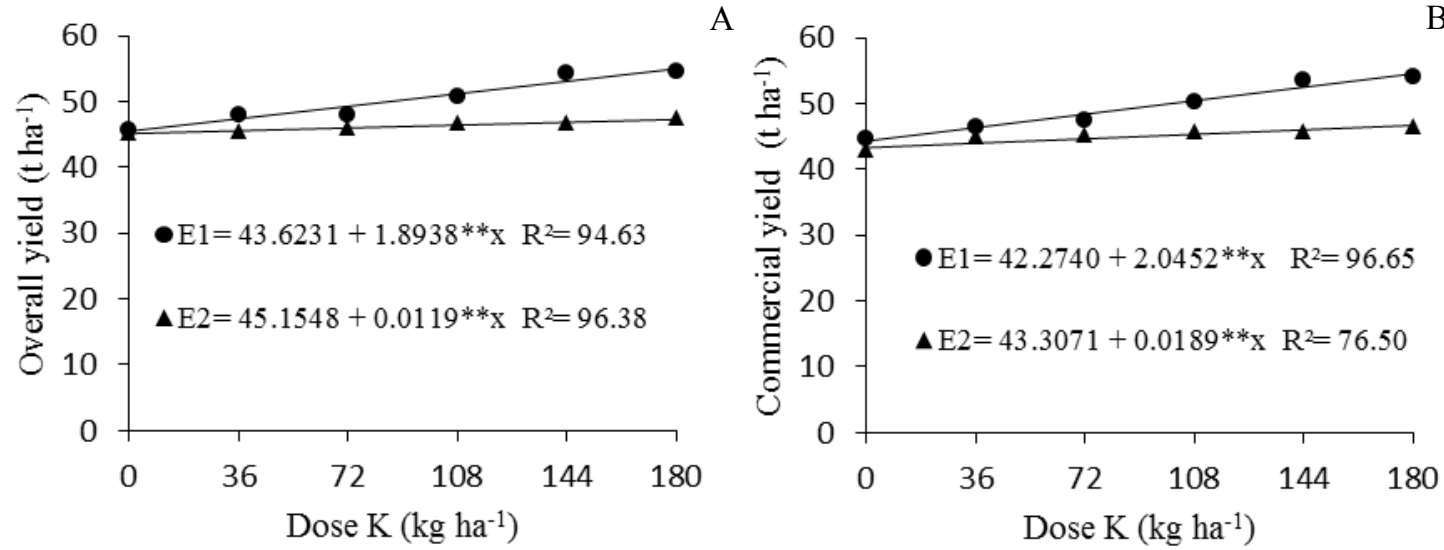

Figure 3. Overall yield (A) and commercial yield (B) of onion bulbs as a function of $\mathrm{K}$ doses and planting time (E1 September to December 2012 and E2 - April to July 2013).

May et al. (2007) assessed the effect of nitrogen and potassium fertilization on onion cultivars and found that treatments without the application of potassium resulted in maximum yields of $68.4 \mathrm{t} \mathrm{ha}^{-1}$ and $71 \mathrm{t} \mathrm{ha}^{-1}$ in Optima and Superex cultivars, respectively. The authors found that potassium had little effect on bulb production and that the $\mathrm{K}$ levels found in the soil provided this nutrient to the culture, and the addition of potassium fertilizers was not required.

The dose that resulted in maximum yields in both experiments $\left(180 \mathrm{~kg} \mathrm{ha}^{-1}\right.$ of $\left.\mathrm{K}_{2} \mathrm{O}\right)$ was higher than that recommended by Cavalcanti (2008), i.e. $135 \mathrm{~kg} \mathrm{ha}^{-1}$ of $\mathrm{K}_{2} \mathrm{O}$ for irrigated onion crops (IPA 11) in soils with potassium concentrations of between 0.16 and $0.30 \mathrm{cmol}_{\mathrm{c}} \mathrm{dm}^{-3}$.

In the treatment without the addition of potassium, estimated overall yields were 44.32 and $43.31 \mathrm{t} \mathrm{ha}^{-1}$ for E1 and E2, respectively, which are considered high, and higher than the Brazilian average yields (27.8 $\mathrm{t} \mathrm{ha}^{-1}$ ) (IBGE, 2016). Potassium concentrations in the soil $\left(0.25\right.$ and $\left.0.28 \mathrm{cmol}_{\mathrm{c}} \mathrm{dm}^{-3}\right)$, which are considered high, according to Cavalcanti (2008), associated with the amount of this nutrient in the irrigation water, $0.54 \mathrm{mmol}_{\mathrm{c}} \mathrm{L}^{-1}$ (data not shown), were sufficient to fulfill the onion culture needs.

The noncommercial bulb yields were not changed by the factors analyzed, with a production of $0.64 \mathrm{t} \mathrm{ha}^{-1}$ and $0.62 \mathrm{t} \mathrm{ha}^{-1}$ of onions in E1 and E2, representing $1.28 \%$ and $1.42 \%$ of the number of bulbs, respectively.

\section{CONCLUSIONS}

Potassium fertilization promoted an increase in the content of $\mathrm{K}$ in the leaf, commercial and total yield, with the maximum obtained in the dose of $180 \mathrm{~kg} \mathrm{ha}^{-1}$ of $\mathrm{K}_{2} \mathrm{O}$. The maximum overall and commercial yields were respectively 54.69 and $54.12 \mathrm{t} \mathrm{ha}^{-1}$ in the experiment of September to December 2012, and 47.39 and 46.39 in that of April to July 2013.

\section{REFERENCES}

AGUIAR NETO, P. et al. Crescimento e acúmulo de macronutrientes na cultura da cebola em Baraúna $(\mathrm{RN})$ e Petrolina (PE). Revista Brasileira de Engenharia Agrícola e Ambiental, Campina Grande, v. 18, n. 4, p. 370-380, 2014.

ARAÚJO, H. S. et al. Doses de potássio em cobertura na cultura da abóbora. Pesquisa Agropecuária Tropical, Goiânia, v. 42, n. 4, p. 469475, 2012.

BUGARÍN-MONTOYA, R. et al. Demanda de potasio del tomate tipo saladette. Terra Latinoamericana, Chapingo, v. 20, n. 4, p. 391-399, 2002.

CAVAlCANTI, F. J. A. Recomendações de adubação para o Estado de Pernambuco: 2a aproximação. 3. ed. Recife, PE: IPA, 2008. 212 p.

CECÍLIO FILHO, A. B. et al. Produtividade e classificação de bulbos de cebola em função da fertilização nitrogenada e potássica, em semeadura direta. Científica, Jaboticabal, v. 38, n. 1-2, p. 14-22, 2010 .

COMPANHIA DE ENTREPOSTOS E ARMAZÉNS GERAIS DO ESTADO DE SÃO PAULO - CEAGESP. Programa Brasileiro para a melhoria dos padrões comerciais e embalagens de hortigranjeiros. São Paulo, 2001.

HAWKESFORD, $M$. et al. Functions of macronutrients. In: MARSCHNER, P. (Ed.). Marschner's mineral nutrition of higher plants. NewYork: Elsevier, 2012. cap. 6, p. 135-178. 
INSTITUTO BRASILEIRO DE GEOGRAFIA E ESTATÍSTICA - IBGE. Produção agrícola municipal 2014. Disponível em: <http:// www.sidra.ibge.gov.br/>. Acesso em: 04 maio. 2016.

KANO, C.; CARDOSO, A. I. I.; BÔAS, R. L. V. Acúmulo de nutrientes e resposta da alface à adubação fosfatada. Biotemas, Florianópolis, v. 25, n. 3, p. 39-47, 2012.

MAY, A. et al. Produtividade de híbridos de cebola em função da população de plantas e da fertilização nitrogenada e potássica. Horticultura Brasileira, Brasília, v. 25, n. 1, p. 53-59, 2007.

RESENDE, G. M.; COSTA, N. D.; PINTO, J. M. Rendimento e conservação pós-colheita de bulbos de cebola com doses de nitrogênio e potássio. Horticultura Brasileira, Brasília, v. 27, n. 2, p. 139 $-143,2009$.

SCIENTIFIC, J. Table curve: curve fitting software. Corte Madera, CA: Jandel Scientific. 1991.

TRANI, P. E.; RAIJ, B. V. Hortaliças. In: RAIJ, B. V. et al. (Eds). Recomendações de adubação e calagem para o Estado da São Paulo. Campinas: IAC, 1997. p. 155-186.

VERMA, D.; SINGH, H. Response of varying levels of potassium and sulphur on yield and uptake of nutrients by onion. Annals of Plant and Soil Research, Azadnaga, v. 14, n. 2, p. 143-146, 2012.

VIDIGAL, S. M.; MOREIRA, M. A.; PEREIRA, P. R. G. Crescimento e absorção de nutrientes pela planta cebola cultivada no verão por semeadura direta e por transplantio de mudas. Bioscience Journal, Uberlândia, v. 26, n. 1, p. 59-70, 2010. 